\title{
Efficiency of botanical pesticides against some pests infesting hydroponic cucumber, cultivated under greenhouse conditions
}

\author{
Muhammad Shoaib Saleem", Tuba Sharf Batool, Muhammad Faheem Akbar, Saboohi Raza and Saleem Shahzad
}

\begin{abstract}
Greenhouse cultivation of vegetables, especially cucumber in hydroponic/soilless culture, has been developed in different parts of the world. There is an expanding interest in hydroponics because they can produce fresh food closer to urban areas. The objective of this study was to evaluate the efficiency of the biopesticides: matrine (extract from Sophora flavescens), spintoram (derived from soil bacterium Saccharopolyspora spinosa), azadirachtin (neem extract), and Annona squamosa (custard apple extract) against the cotton aphid (Aphis gossypii Glov.) and the twospotted spider mite, (Tetranychus urticae Koch.). A drip-irrigation hydroponics system (DIHS) was designed and used for this study. Fourteen-day-old seedlings of cucumber plants were shifted in DIHS, and nutrient requirements were maintained during the period of experiment. Randomized complete block design (RCBD) was used for this experiment with 3 replicates and with 5 treatments. Data were collected $24 \mathrm{~h}$ pre-treatment and 1, 3, 7, and 14 days post-treatment. Results revealed that the custard apple extract showed the highest efficiency (80 and 76\%) reduction against the aphid and the mite, respectively, followed by matrine (legend) and neem extract (73\%), and spintoram (radiant) (69\%) in case of the aphid, while it was followed by matrine (legend) (75\%), spintoram (radiant), $(66 \%)$, and neem extract (56\%) in the case of the mite.
\end{abstract}

Keywords: Biopesticides, Cucumber, Greenhouse, Hydroponics, Aphids, Two-spotted spider mite

\section{Introduction}

Cucumber (Cucumis sativus L.) is one of the global horticultural crops (Eifediyi and Remison 2010). For obtaining ample amount of yield and better quality in protected cultivation systems, greenhouse conditions and hydroponics are considered effective (Preciado Rangel et al. 2011). In greenhouses, the two-spotted spider mite (Tetranychus urticae Koch) is one of the most polyphagous and serious pests (Attia et al. 2013). As well, the cotton aphid (Aphis gossypii Glov.) is also a cosmopolitan insect pest that infests more than 569 plant species under 103 families (Tazerouni et al. 2016).

In recent years, plant extracts and botanical pesticides have showed great importance in agricultural fields due to their cheap and low expenses, with no residual effects, environmentally friendly, and highly toxic against major pests such as thrips, aphids, jassids, whitefly, and mites

\footnotetext{
* Correspondence: shoaibsaleeemkhan@gmail.com

Department of Agriculture and Agribusiness Management, University of Karachi, Main University Road, Karachi, Karachi City, Sindh 75270, Pakistan
}

(Stumpf and Nauen 2001). The extract of Annona squamosa L. (family Annonaceae), commonly known as Sita phal, and the sweetsop and custard apple have shown potentials for pest control across a large array of insect pests. Laboratory and field experiments proved that custard apple extract effectively managed different field crop pests and stored grain pests (Misra 2000). Synthetic pesticides have many drawbacks as they are persistence, develop resistance in pests, and affect non-target organisms such as natural enemies. Contrary to the chemical pesticides, biopesticides are eco-friendly as the non-target organisms and human beings are less affected (Begum et al. 2013). Alkaloid matrine is the active ingredient obtained from the dry roots of Sophora flavescens Ait, which is richly found in the roots of few species from the genus Sophora (Mao and Henderson 2007). It has high toxicity against various insect pests and used for the management of leafhoppers, mites, aphids, and caterpillars and bacterial and fungal diseases (Marcic et 
al. 2012). Moreover, it is also used for the management of stored commodities pests (Liu et al. 2007).

Neem oils and extracts are considered as the best option for the insect pest management program in vegetables because they are safe for beneficial organisms, target-specific, and compatible for biological control agents (Tang et al. 2002). Spintoram is a reduced risk insecticide from a novel class of chemicals spinosyns (Srivastaba et al. 2008).

The present study demonstrates the efficiency of 4 products of bioinsecticides. Matrine, spintoram, neem, and custard apple extracts against Tetranychus urticae Koch and Aphis gossypii Glov. on hydroponic cucumber cultivation under greenhouse conditions.

\section{Materials and methods}

\section{Nursery preparation and drip irrigation hydroponics system (DIHS) design}

Experiments were conducted at the Zain Advanced Growing Research Facility (ZAGF), Department of Agriculture and Agribusiness Management, University of Karachi, during the year 2018. Leeza (F1 hybrid) cucumber variety was used as a host for the tested pest. Cucumber nursery was prepared in sterilized coco peat seedling trays. After 20 days of germination, the seedlings were transplanted into DHIS. The system was designed, using 15-ft polyvinyl chloride (PVC) pipe of 6-in. diameter, and 2 -in. holes were done in pipes. Hole to hole distance in each pipe was 6 in., while pipe to pipe distance was $18 \mathrm{in}$. There was an inlet and outlet at the opposite ends of the PVC pipe. Two inches of hydroponic net cup was used in this study. Cucumber seedlings were shifted in each cup with coco peat in net cups. A tank with a capacity of $30 \mathrm{l}$ was connected to the system. A submersible pump with motor was connected to the inlet of PVC pipe and the outlet was connected to the tank. Half-inch drip irrigation pipe with emitters were installed on the PVC pipes. Nutrients were prepared according to Hoagland's nutrient recipe Hoagland and Arnon (1950).

\section{Custard apple (Annona squamosa L.) seed extraction}

During 2018, fresh fruits of custard apple were procured from the local market of Karachi, and seeds were removed from them after washing with tap water. Seeds were left to dry in shade and smashed in an electric grinder. Thereafter, powdered seeds were mixed with methyl alcohol (70\%) in the ratio of $1: 3$ $(w / v)$, i.e., $100 \mathrm{~g}$ seed powder and $300 \mathrm{ml}$ methyl alcohol. The mixture of seed and alcohol was agitated well every $8 \mathrm{~h}$ for 6 times. The supernatant of the solution was filtered by using Whatman's filter paper after $48 \mathrm{~h}$. The amount of solution thus was obtained about $200 \mathrm{ml}$. Volume of filtered supernatant was adjusted to $400 \mathrm{ml}$ by adding $200 \mathrm{ml}$ methyl alcohol additionally. After completing extraction, the mixture was brought for condensation through evaporation in an evaporating chamber. After evaporation, $100-\mathrm{ml}$ volume was considered as $100 \%$ seed extract, which was used as biopesticides for further study (Arain 2017).

\section{Experimental design and biopesticides application}

Experiments were arranged in a randomized complete block design (RCBD) by Sokal and Rohlf (1981), with 3 replicates for each biopesticide. Each comprising 5 treatments including control. Plants were monitored for mite and aphid infestation, and application of biopesticides was carried out, when the population of the pests reached the economic threshold level (ETL), i.e., 5-10 for mites per leaf (Walgenbach 2015) and 5-7 aphids per leaf (Afshari et al. 2009). Biopesticides were prepared according to the recommended dose mentioned on the label, i.e., matrine at $6.17 \mathrm{~g}$ a.i./ha, spintoram at $296.4 \mathrm{~g}$ a.i./ha, azadirachtin at $1.58 \mathrm{~g}$ a.i./ha, and custard apple at $247 \mathrm{~g}$ a.i./ha. Spray was done using a handheld sprayer at dusk time. Population density of the mite and aphid was recorded on 10 selected plants at each treatment. Three leaves/plants were selected from top, middle, and bottom (Kaushik et al. 1990), and pests were carefully counted on under side of the leaves. Collected data were expressed as mean populations at each plot. Pre-treatment counts were taken 1 day before treatments, while the post-treatment counts were undertaken after one, 3,7 , and 14 days of spray.

\section{Statistical analysis}

Obtained data were compiled in two manners: as a change in percent population density and efficacy percentage relative to the untreated (control) plots. The change in population density was calculated as follows:

Change in Population Density $(\mathrm{CPD} \%)=[(X i-X 0) /$ $X 0] \times 100$

where $X 0$ is the mean number of live insects before treatment, $X i$ is the mean number of live insects at the assessment after treatment. Positive values in the table indicate an increase.

The reduction percentage was calculated by HendersonTilton's formula (Henderson and Tilton 1955) according to the following equation:

$\%$ reduction in population $=100 \times 1-\left(\frac{T_{a} \times C_{b}}{T_{b} \times C_{a}}\right)$

where:

$T_{a}=$ number of insects after treatment

$T_{b}=$ number of insects before treatment

$C_{a}=$ number of insects in control plots after treatment $C_{b}=$ number of insects in control plots before treatment

The collected data were subjected to statistical analysis through SPSS version 16.0. The mean differences between various treatments were tested by using Tukey's HSD test at 5\% significance level. 


\section{Results and discussion}

The biopesticides applied at the recommended dose significantly reduced the mean number of live insect and showed high efficacy in controlling Tetranychus urticae and Aphis gossypii.

\section{Efficiency of the biopesticides against Aphis gossypii}

One day post-treatment (Table 1), spintoram showed a maximum reduction in A. gossypii population by (59\%), with the efficacy of $46 \%$, followed by azadirachtin, custard apple, and matrine that reduced the population $(49,38$, and $18.3 \%$ ) with the efficacy of 46,31 , and $39 \%$, respectively. Three days post-treatments, maximum reduction was recorded by the custard apple (95\%) with the efficacy of $95 \%$, matrine and azadirachtin showed 83 and $79 \%$ population reduction with 87 and $81 \%$ efficacy, respectively, followed by spintoram (46\%) reduction with $49 \%$ efficacy. Seven days post-treatments, custard apple showed the highest population reduction (97\%) with the efficacy of $98 \%$, azadirachtin and spintoram showed 82 and $85 \%$ reduction with 28 and $81 \%$ efficacy, respectively, followed by matrine $(84 \%)$ reduction with $69 \%$ efficacy. Meanwhile, after 14 days of treatment, spintoram showed the highest population reduction (94\%) with the efficacy of 99\%, matrine and custard apple showed 94 and $91 \%$ reduction with 97 and 93\% efficacy, respectively, followed by azadirachtin (86\%) reduction with 86\% efficacy against $A$. gossypii.

An overall performance of all the pesticides (Table 1 and Fig. 1) represents that the custard apple extract was the highly effective one against the aphid, followed by azadirachtin, matrine, and spintoram $(80,73,73$, and $69 \%)$, respectively.

Efficiency of the biopesticides against Tetranychus urticae One day post-treatments (Table 2), matrine showed the maximum reduction of $T$. urticae population by $60 \%$, with the efficacy of $76 \%$, followed by azadirachtin, spintoram, and custard apple $(16,3$, and $1 \%)$ with the efficacy of 47,41 , and $33 \%$, respectively. Three days post-treatments, the maximum reduction was recorded in custard apple (82\%) with the efficacy of $91 \%$, azadirachtin and matrine showed 54 and 19\% reduction with 79 and $62 \%$ efficiency, respectively, followed by spintoram (5\%) reduction with $53 \%$ efficiency. Seven days post-treatments, custard apple showed the highest population reduction (90\%) with the efficacy of $89 \%$, spintoram and matrine showed 75 and $72 \%$ reduction with 78 and 69\% efficacy, respectively, followed by azadirachtin $(26 \%)$ reduction with $31 \%$ efficacy. Meanwhile, after 14 days of treatments, matrine showed the highest population reduction (91\%) with the efficacy of $88 \%$, spintoram and custard apple showed 91 and $92 \%$ reduction with 86 and $85 \%$ efficacy, respectively, followed by azadirachtin (51\%) reduction and 31\% efficacy.

An overall performance of all the biopesticides (Table 2 and Fig. 2) represents that custard apple extract was highly effective against the mite, followed by matrine, spintoram, and azadirachtin (76, 75, 66 and 56\%), respectively.

Figure 3 shows the comparative efficacy data of all treatments. Eventually, it endorses the performance of biopesticides by an overall effect in the treatments against $T$. urticae and $A$. gossypii that ranked as custard apple extract, azadirachtin, matrine, and spintoram.

Biopesticides differ in their mode of actions. According to the US Environmental Protection Agency (EPA), biorational insecticides exhibit minimum risk to the environment, break down quickly, have minimum residue, and are safe for applicant, and a comparatively small quantity is required for booming control of target organisms (Sadeghi et al. 2009). The findings of the present study revealed that custard apple had the topmost effect over the 2 pests: $T$. urticae and A. gossypii.

Table 1 Population densities of Aphis gossypii ( $N$ ) on hydroponic cucumber and effectiveness of biopesticides

\begin{tabular}{|c|c|c|c|c|c|c|c|c|c|c|c|c|c|}
\hline \multirow[t]{2}{*}{ Treatments } & \multirow[t]{2}{*}{ Before spray } & \multicolumn{3}{|l|}{ After $24 \mathrm{~h}$} & \multicolumn{3}{|l|}{ After $72 \mathrm{~h}$} & \multicolumn{3}{|l|}{ After $168 \mathrm{~h}$} & \multicolumn{3}{|l|}{ After $336 \mathrm{~h}$} \\
\hline & & $\bar{N}$ & $\begin{array}{l}\text { CPD } \\
(\%)\end{array}$ & $\begin{array}{l}\mathrm{EF} \\
(\%)\end{array}$ & $\bar{N}$ & $\begin{array}{l}\text { CPD } \\
(\%)\end{array}$ & $\begin{array}{l}\mathrm{EF} \\
(\%)\end{array}$ & $\bar{N}$ & $\begin{array}{l}\text { CPD } \\
(\%)\end{array}$ & $\begin{array}{l}\mathrm{EF} \\
(\%)\end{array}$ & $\bar{N}$ & $\begin{array}{l}\text { CPD } \\
(\%)\end{array}$ & $\begin{array}{l}\mathrm{EF} \\
(\%)\end{array}$ \\
\hline Matrine & $23.6^{a}$ & $19.3^{\mathrm{ab}}$ & -18.3 & 39 & $4.0^{\mathrm{a}}$ & -83.0 & 87 & $3.6^{\mathrm{a}}$ & -84.5 & 69 & $1.3^{\mathrm{a}}$ & -94.3 & 97 \\
\hline Spintoram & $35.6^{\mathrm{a}}$ & $14.3^{\mathrm{a}}$ & -59.8 & 46 & $19.0^{\mathrm{ab}}$ & -46.7 & 49 & $5.0^{\mathrm{a}}$ & -85.9 & 81 & $2.0^{\mathrm{a}}$ & -94.3 & 99 \\
\hline Azadirachtin & $81.3^{a}$ & $41.0^{\mathrm{ab}}$ & -49.5 & 46 & $17.0^{\mathrm{ab}}$ & -79.0 & 81 & $14.0^{\mathrm{a}}$ & -82.7 & 82 & $10.6^{\mathrm{a}}$ & -86.8 & 86 \\
\hline $\begin{array}{l}\text { Custard } \\
\text { apple }\end{array}$ & $74.3^{\mathrm{a}}$ & $45.6 \mathrm{~b}$ & -38.5 & 31 & $3.6^{\mathrm{a}}$ & -95.0 & 95 & $2.0^{\mathrm{a}}$ & -97.3 & 98 & $6.3^{\mathrm{a}}$ & -91.4 & 93 \\
\hline Control & $27.6^{a}$ & $31.6^{\mathrm{ab}}$ & 15.8 & & $39.3^{b}$ & 43.9 & & $32.0^{\mathrm{b}}$ & 17.0 & & $33.3^{b}$ & 21.9 & \\
\hline $\begin{array}{l}\text { Significance } \\
\text { level }\end{array}$ & $\begin{array}{l}F=2.10 ; d f=4 \\
P \geq 0.05\end{array}$ & $\begin{array}{l}F=4.43 ; \mathrm{df}=4 \\
P \leq 0.05\end{array}$ & & & $\begin{array}{l}F=4.38 ; \mathrm{df}=4 \\
P \leq 0.05\end{array}$ & & & $\begin{array}{l}F=13.8 ; d f=4 ; \\
P \leq 0.01\end{array}$ & & & $\begin{array}{l}F=30.8 ; d f=4 \\
P \leq 0.01\end{array}$ & & \\
\hline
\end{tabular}

The mean number of aphids/leaf (30 leaves per plot); within a column, the means pursued by the same letter are not significantly different (Tukey's HSD test, $a=0.05$ )

$C P D(\%)$ change in population density, EF (\%) percent efficacy (Henderson-Tilton formula) 


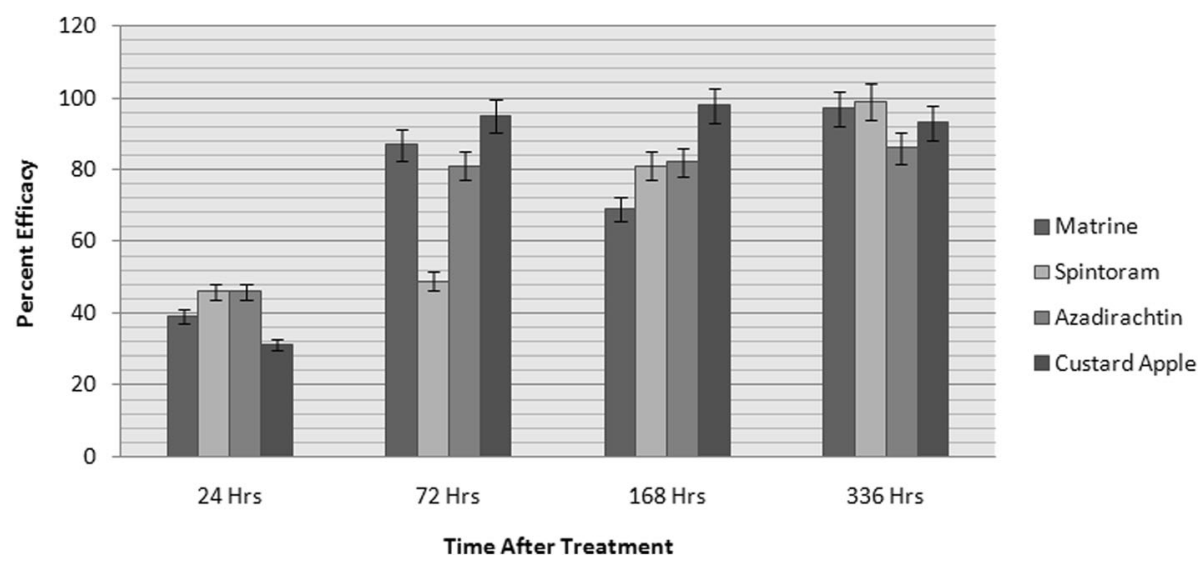

Fig. 1 Comparative efficacy of biopesticides against Tetranychus urticae Koch and Aphis gossypii.

It is reported that the seed of A. squamosa has insecticidal and causative properties. Previous studies showed that crude oils from seeds of A. squamosa significantly reduced leaf damage caused by Spodoptera litura when applied at 2.5\% concentrations (Babu et al. 1998). The population of Callosobruchus maculatus was also reduced when extracts of fresh seeds of $A$. squamosa were applied with acetone (Dharmasena et al. 2001). In this study, seed extract was prepared in absolute alcohol, which was highly effective against $T$. urticae $(76 \%)$ and A. gossypii on $80 \%$ on hydroponics cucumber crop under greenhouse conditions (Table 2). Sonkamble et al. (2000) found that the seed extract at $1.5 \%$ concentration had the maximum mortality against Helicoverpa armigera (43.33\%) and $36.66 \%$ percent mortality at $1 \%$ concentration against $S$. litura. It is reported that A. squamosa seed extract had repellent and anti-oviposition properties against Ceratitis capitata (Epino and Chang 1993). Topical application of $A$. squamosa seed extract showed a substantial decline of all 5th instar larvae of Dysdercus koenigii, which rise in fresh free amino acid under laboratory conditions (Reddy et al. 1993).

In the present study, biopesticide derived from $S$. flavescens (Ait.) matrine showed high effectiveness in comparison to spintoram. The findings of this study is supported by many previous studies, which indicated that matrine is very effective for the management of sucking insect pest. In Brazil, it succeeded to reduce the infestation with Planococcus citri and Eutetranychus banksi, in a commercial citrus farm (Zanardi et al. 2015). In another study, results showed that the most efficient treatment was matrine (2 l/ha) against diamondback moth, Plutella xylostella. Matrine, when applied at the rate of $2 \mathrm{l} / \mathrm{ha}$ and $1.5 \mathrm{l} / \mathrm{ha}$, showed similar efficacy until 15 days of post-treatment. However, matrine (2 l/ ha) found much better when assessed 20 days post-treatment. Overall, after 20 days of pesticide application matrine (2l/ha) showed the highest efficacy (89.9\%), followed by matrine $1.5 \mathrm{l} /$ ha (Karimzadeh 2014). Additionally, it is also reported that matrine can be

Table 2 Population densities of Tetranychus urticae $(N)$ on hydroponic cucumber and effectiveness of biopesticides

\begin{tabular}{|c|c|c|c|c|c|c|c|c|c|c|c|c|c|}
\hline \multirow[t]{2}{*}{ Treatments } & \multirow[t]{2}{*}{ Before spray } & \multicolumn{3}{|l|}{ After $24 \mathrm{~h}$} & \multicolumn{3}{|l|}{ After $72 \mathrm{~h}$} & \multicolumn{3}{|l|}{ After $168 \mathrm{~h}$} & \multicolumn{3}{|l|}{ After $336 \mathrm{~h}$} \\
\hline & & $N$ & $\begin{array}{l}\text { CPD } \\
(\%) \\
\end{array}$ & $\begin{array}{l}\mathrm{EF} \\
(\%)\end{array}$ & $N$ & $\begin{array}{l}\text { CPD } \\
(\%)\end{array}$ & $\begin{array}{l}\mathrm{EF} \\
(\%)\end{array}$ & $N$ & $\begin{array}{l}\text { CPD } \\
(\%) \\
\end{array}$ & $\begin{array}{l}\mathrm{EF} \\
(\%)\end{array}$ & $N$ & $\begin{array}{l}\text { CPD } \\
(\%)\end{array}$ & $\begin{array}{l}\mathrm{EF} \\
(\%) \\
\end{array}$ \\
\hline Matrine & $28.6^{a}$ & $11.3^{\mathrm{a}}$ & -60.4 & 76 & $23.0^{\mathrm{a}}$ & -19.7 & 62 & $8.0^{\mathrm{a}}$ & -72.0 & 69 & $2.3^{\mathrm{a}}$ & -91.8 & 88 \\
\hline Spintoram & $26.3^{a}$ & $25.3^{\mathrm{a}}$ & -3.7 & 41 & $27.6^{\mathrm{ab}}$ & 5.0 & 53 & $6.3^{\mathrm{a}}$ & -75.9 & 78 & $2.3^{a}$ & -91.1 & 86 \\
\hline Azadirachtin & $30.0^{\mathrm{a}}$ & $25.0^{\mathrm{a}}$ & -16.6 & 47 & $13.6^{\mathrm{a}}$ & -54.4 & 79 & $22.0^{\mathrm{b}}$ & -26.6 & 31 & $14.6^{\mathrm{b}}$ & -51.1 & 31 \\
\hline $\begin{array}{l}\text { Custard } \\
\text { apple }\end{array}$ & $33.3^{\mathrm{a}}$ & $33.3^{\mathrm{a}}$ & -1.0 & 33 & $6.0^{\mathrm{a}}$ & -82.0 & 91 & $3.3^{\mathrm{a}}$ & -90.0 & 89 & $2.6^{a}$ & -92.0 & 85 \\
\hline Control & $40.3^{a}$ & $67.6^{\mathrm{b}}$ & 67.7 & & $88.3^{b}$ & 119 & & $45.6^{c}$ & 13.2 & & $55.0^{c}$ & 36.3 & \\
\hline $\begin{array}{l}\text { Significance } \\
\text { level }\end{array}$ & $\begin{array}{l}F=0.61 ; d f=4 \\
P \geq 0.05\end{array}$ & $\begin{array}{l}F=19.6 ; \mathrm{df}= \\
4 ; P \leq 0.01\end{array}$ & & & $\begin{array}{l}F=5.52 ; \mathrm{df}=4 \\
P \leq 0.01\end{array}$ & & & $\begin{array}{l}F=95.9 ; \mathrm{df}=4 \\
P \leq 0.01\end{array}$ & & & $\begin{array}{l}F=12.5 ; \mathrm{df}=4 \\
P \leq 0.01\end{array}$ & & \\
\hline
\end{tabular}

The mean number $(N)$ of mites/leaf (30 leaves per plot); within a column, the means pursued by the same letter are not significantly different (Tukey's HSD test, $a=0.05$ )

$C P D(\%)$ change in population density, EF (\%) percent efficacy (Henderson-Tilton formula) 


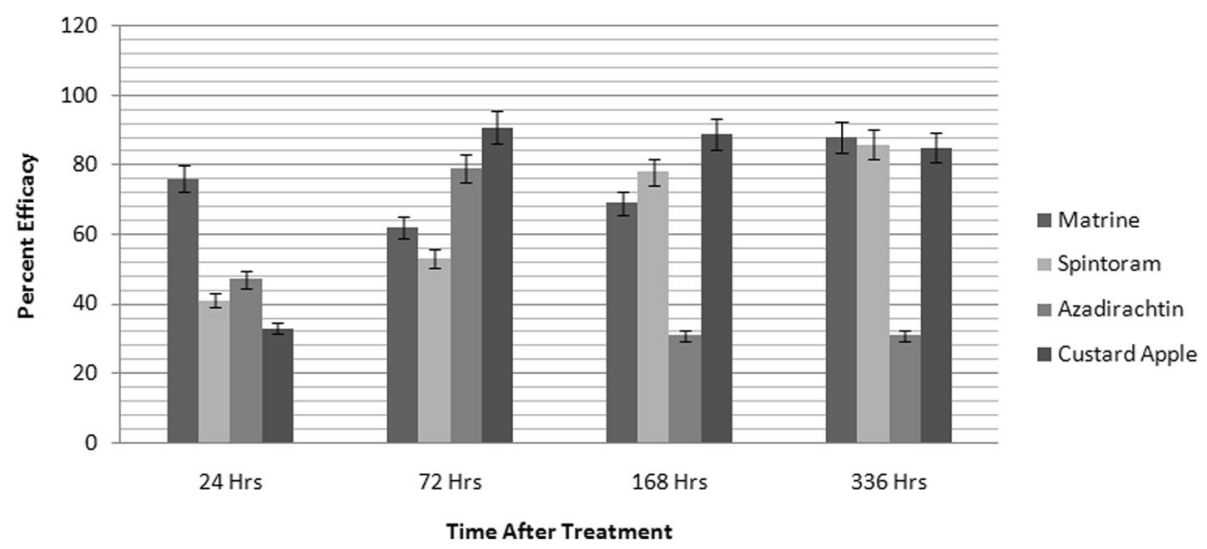

Fig. 2 The percent mortality of Aphis gossypii at different days after spraying in the greenhouse

useful to control spider mites without causing any phytotoxic problems, which is one of the very serious issue associated with the use of botanical pesticides in citrus seedlings (Cloyd et al. 2009).

Neem-based products (azadirachtin) which are commercially available in the market have varied pest control properties, disturbing insect growth stages, fertility, and anti-feeding activity, in addition to their direct toxicity and oviposition restrain changes (Naqvi 1996). Obtained findings indicated that azadirachtin had a moderate efficacy (69 and 56\%) against A. gossypii and T. urticae, respectively, on hydroponic cucumber, which is probably due to its mode of action and which is different from synthetic compounds. For example, the efficacy of different neem-based formulations and synthetic compounds against cabbage butterfly (Pieris brassicae) has been studied. The results indicated that all synthetic compounds had $100 \%$ efficacy after $72 \mathrm{~h}$ treatment, which was higher than neem-based compounds. It is found that neem oil formulation was effective for the management of aphid population than the treatment with neem oil or control plants. Similarly, numerous other neem-based products showed effectiveness of Myzus persicae on several host plants (Akbar et al. 2010). The neem extract was extremely effective to control jassid, whitefly, aphid, and mites on brinjal (Ali et al. 2017).

Spintoram is a relatively newer biopesticide and has shown good efficacy against $T$. urticae and A. gossypii on on hydroponic cucumber crop under greenhouse conditions. The findings of the present study are similar to the study conducted by El Kady et al. (2007) as all doses of spintoram caused reduction of infestations of different stages of $T$. urticae. The maximum reduction was observed in egg treatment (100\%) after 13 and 19 days. For adult, $96.7 \%$ reduction was recorded after 5 days and $87.5 \%$ mortality was observed in immature stages after 11 days at dose $1 \mathrm{ml}$ solution/liter water. Wang et al. (2016) reported that spintoram also reduced the developmental time of $T$. urticae from egg to adult when treated with $\mathrm{LC}_{10}$ and $\mathrm{LC}_{20}$. Spintoram also hinders the egg duration, mean generation time, and larval duration of insect whether adult females or eggs were poisoned. Due to some broad spectrum activity of spinosyns, it is reported that they are effective against many insects from different orders like Diptera, Homoptera, Isoptera, Thysanoptera, Orthoptera, and Coleoptera (Salgado 1998). Mahmoud

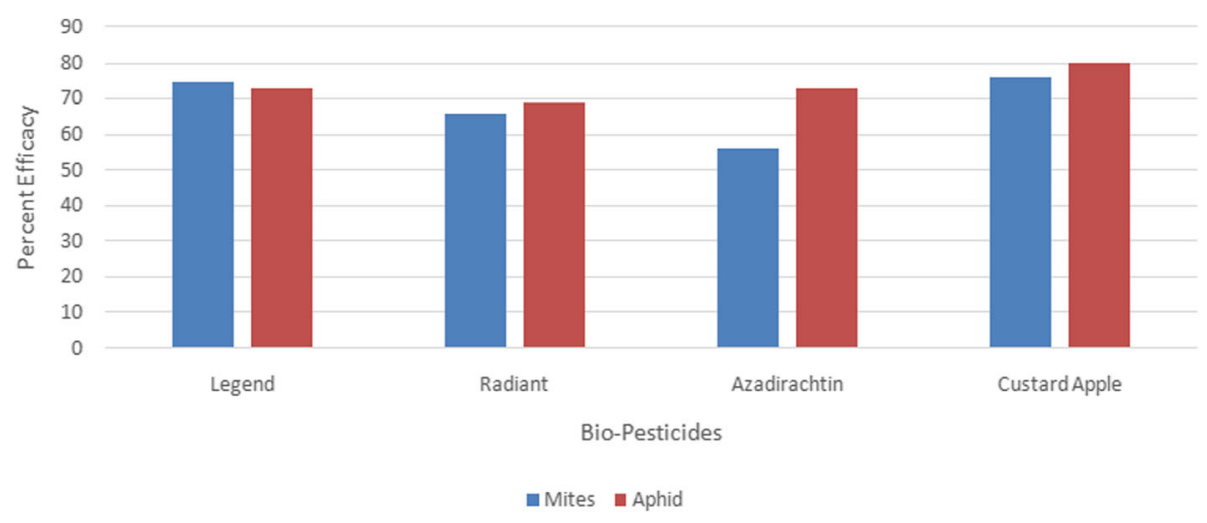

Fig. 3 The percent mortality of Tetranychus urticae at different days after spraying in the greenhouse 
and Osman (2007) reported that Spinosad showed the maximum mortality against the populations of Thrips tabaci on onion crop till 21 days after treatment.

\section{Conclusion}

In conclusion, according to the findings of the present research, custard apple extract and matrine showed excellent results against Tetranychus urticae and Aphis gossypii on hydroponics cucumber under greenhouse conditions. However, neem extract was very effective against aphids as compare to mites. Increasing market trend and awareness of pesticide residue-free vegetables, consumeable after the harvest, efforts to slow down or underrate pest resistance to synthetic pesticides (Fournier and Brodeur 2000) and balanced insecticidal activities (Baldwin 2008), the bio rational insecticide of the plant origin could be suggested for the management of Tetranychus urticae on hydroponics cucumber under greenhouse plantings in an IPM program.

\section{Acknowledgments}

The authors are thankful to Advanced Growing Technologies (AGTECH) for providing funding and infrastructure of research facility.

\section{Funding}

The funders had no role in study design, data collection and analysis, decision to publish, or preparation of the manuscript.

\section{Availability of data and materials}

The datasets used and/or analyzed during the current study are available from the corresponding author on reasonable request.

\section{Authors' contribution}

MSS conducted the experiment, data collection, and data analysis, wrote the results and discussion, and collected references and literature. TSB conducted the experiment, data collection, and data analysis, wrote the abstract and introduction, and collected references and literature. MFA conceived the idea and conducted the overall management of the article. SR reviewed the manuscript and contributed to the data analysis. SS reviewed the manuscript. All authors read and approved the final manuscript.

\section{Authors' information \\ 1. Muhammad Shoaib Saleem Ph.D Scholar, Visiting Lecturer \\ 2. Tuba Sharf Batool Ph.D Scholar, Teaching Associate \\ 3. Muhammad Faheem Akbar Ph.D, Assistant Professor \\ 4. Saboohi Raza Ph.D, Associate Professor/Chairperson \\ 5. Saleem Shahzad Ph.D, Professor}

Ethics approval and consent to participate

Not applicable

\section{Consent for publication}

Not applicable

\section{Competing interests}

The authors declare that they have no competing interests.

\section{Publisher's Note}

Springer Nature remains neutral with regard to jurisdictional claims in published maps and institutional affiliations.
Received: 13 December 2018 Accepted: 9 May 2019

Published online: 03 June 2019

\section{References}

Afshari, A., E. Soleiman-Negadian, and P. Shishebor (2009) Popualiton density and spatial distribution of Aphis gossypii Glover (Homoptera: Aphididae) on cotton in Gorgan, Iran , J Agric Sci Technol 11 (2): 27-38

Akbar M.F., Haq M.A., Parveen F., Yasmin N., Farhan M., Khan U. (2010). Comparative management of cabbage aphid (Myzus persicae (Sulzer) (Aphididae: Hemiptera) through bio- and synthetic insecticides. Pakistan Entomol 32 (1):12-17

Ali SS, Ahmed SS, Rizwana H, Bhatti F, Khoso A, Mengal MI, Shahwani SA (2017) Efficacy of different bio-pesticides against major sucking pests on brinjal under field conditions. J Basic Appl Sci 13(1):133-138

Arain QA (2017) Studies of systemic insecticides and custard apple Annona squamosa L. seed extract effects on cotton pest Spodoptera litura Fab., with reference to transgenic and conventional cotton varieties. Department of Agriculture and Agribusiness Management, University of Karachi, Karachi 75270, Pakistan. Ph. D thesis, p 43

Attia S, Grissa KL, Lognay G, Bitume E, Hance T, Mailleux AC (2013) A review of the major biological approaches to control the worldwide pest Tetranychus urticae (Acari: Tetranychidae) with special reference to natural pesticides. J Pest Sci 86(3):361-386

Babu PBS, Rao JM, Joy B (1998) Effect of crude oils of Annona squamosa and A. reticulata on feeding and development of Spodoptera litura (Fab.) larvae. J Insect Sci 11(2):184-185

Baldwin R (2008) Soaps as insecticides. In: Capinera JL (ed) Encyclopedia of entomology. 2nd Ed. V. 1-4. Springer, Dordrecht, pp 3433-3439

Begum N, Sharma B, Pandey RS (2013) Calotropisprocera and Annona squamosa: potential alternatives to chemical pesticides. British J Appl Sci Technol 3(2):254

Cloyd RA, Galle CL, Keith SR, Kalscheur NA, Kemp KE (2009) Effect of commercially available plant-derived essential oil products on arthropod pests. J Econ Entomol 102(4):1567-1579

Dharmasena CMD, Blaney WM, Simmonds MSJ (2001) Effect of storage on the efficacy of powdered leaves of Annona squamosa for the control of Callosobruchus maculatus on cowpeas (Vigna unguiculata). Phytoparasitica 29(3):191-196

Eifediyi EK, Remison SU (2010) Growth and yield of cucumber (Cucumissativus L.) as influenced by farmyard manure and inorganic fertilizer. J Plant Breeding and Crop Sci 2(7):216-220

El Kady GA, El Sharabasy HM, Mahmoud MF, Bahgat IM (2007) Toxicity of two potential bio-insecticides against moveable stages of Tetranychus urticae Koch. J Appl Sci Res 3(11):1315-1319

Epino PB, Chang F (1993) Insecticidal activity of Annona squamosa L. seed extracts against the mediterranean fruit fly, Ceratitis capitata (Wiedemann) (Diptera: Tephritidae). Philippine Entomologist 9(2):228-238

Fournier V, Brodeur J (2000) Dose-responses susceptibility of pest aphids (Homoptera: Aphididae) and their control on hydroponically grown lettuce with the entomopathogenic fungus Verticillium lecanii, azadirachtin and insecticidal soap. Environ Entomol 29(3):568-578. https://doi.org/10.1603/0046-225X

Henderson CF, Tilton EW (1955) Tests with acaricides against the brown wheat mite. J Econ Entomol 48(2):157-161

Hoagland, D. R., \& Arnon, D. I. (1950). The water-culture method for growing plants without soil. Circular. California agricultural experiment station, 347(2nd edit)

Karimzadeh, Javad (2014). The efficacy of a new insecticide, Rui Agro ${ }^{\circledast}$ (matrine), against the diamondback moth. http://agris.fao.org/agrissearch/search. do? recordID=IR2016000023

Kaushik S, Prakash A, Singh A (1990) Inelastic buckling of ferrocement encased columns

Liu ZL, Goh SH, Ho SH (2007) Screening of Chinese medicinal herbs for bioactivity against Sitophilus zeamais Motschulsky and Tribolium castaneum (Herbst). J Stored Prod Res 43(3):290-296

Mahmoud MF, Osman MAM (2007) Relative toxicity of some bio-rational insecticides to second instar larvae and adults of onion thrips (Thrips tabaci Lind.) and their predator Orius albidipennis under laboratory and field conditions. J Plant Protection Res 47(4):391-400

Mao L, Henderson G (2007) Antifeedant activity and acute and residual toxicity of alkaloids from Sophora flavescens (Leguminosae) against Formosan subterranean termites (Isoptera: Rhinotermitidae). J Econ Entomol 100(3):866-870 
Marcic D, Prijovic M, Drobnjakovic T, Medo I, Peric P, Milenkovic S (2012) Greenhouse and field evaluation of two biopesticides against Tetranychus urticae and Panonychus ulmi (Acari: Tetranychidae). Pesticide Phytomed 27(2):313-320

Misra $\mathrm{H}$ (2000) Effectiveness of indigenous plant products against the pulse beetle, Callosobruchus chinensis on stored black gram. Indian J Entomol 62:218-220

Naqvi SNH (1996) Prospects and development of a neem based pesticide in Pakistan. Proceedings of the 16th Congress of Zoology, Islamabad. 16, pp 325-338

Preciado Rangel P, Fortis Hernández M, García-Hernández UL, Rueda Puente EO, Esparza Rivera JR, Lara Herrera A, Orozco Vidal JA (2011) Evaluación de soluciones nutritivas orgánicas en la producción de tomate en invernadero. Interciencia 36(9)

Reddy KD, Bhagawan CN, Sukumar K (1993) Depletion of amino acids and protein in the nymphal haemolymph of the red cotton bug, Dysdercus koenigii (Fab.) (Hemiptera: Pyrrhocoridae) treated with Annona squamosa extract. Phytophaga 5(1):45-50

Sadeghi A, Van Damme EM, Smagghe G (2009) Evaluation of the susceptibility of the pea aphid, Acyrthosiphon pisum, to a selection of novel biorational insecticides using an artificial diet. J Insect Sci 9(1):1-8. https://doi.org/10. 1673/031.009.6501

Salgado VL (1998) Studies on the mode of action of Spinosad: insect symptoms and physiology correlates. Pestic Biochem Physiol 60(2):91-102

Sokal RR, Rohlf FJ (1981) Biometry: the principles and practice of statistics in biological research, 2nd edn. W. H. Freeman and Company, New York

Sonkamble MM, Dhanorkar BK, Munde AT, Sonkamble AM (2000) Efficacy of indigenous plant extracts against Helicoverpa armigera (Hubner) and Spodoptera litura (Fabricius) under laboratory conditions. J Soils Crops 10(2):236-239

Srivastaba M, Bosco L, Funderburk J, Olson S, Weiss A (2008) Spinetoram is compatible with the key natural enemy of Frankliniella species thrips in pepper. Plant Health Progress 9(1):30-35. https://doi.org/10.1094/PHP2008-0118-02-RS

Stumpf N, Nauen R (2001) Cross-rsistance, inheritance, and biochemistry of mitochondrial electron transport inhibitor- acaricide resistance in Tetranychus urticae (Acari: Tetranychidae). J Econ Entomol 94:1577-1583

Tang, Y.Q., Weathersbee A.A., Mayer R.T (2002). Effect of neem extract on the brown citrus aphid (Homoptera: Aphididae) and its parasitoid Lysiphlebus testaceipes (Hymenoptera: Aphididae). Environ Entomol 31(1): 172-176

Tazerouni Z, Talebi AA, Fathipour Y, Soufbaf M (2016) Bottom-up effect of two host plants on life table parameters of Aphis gossypii (Hemiptera: Aphididae). J Agric Sci Technol 18(1):179-190

Walgenbach Jim (2015). Extension entomology specialist (fruits/vegetables) entomology. https://content.ces.ncsu.edu/twospotted-spider-mite

Wang L, Zhang Y, Xie W, Wu Q, Wang S (2016) Sublethal effects of spinetoram on the two-spotted spider mite, Tetranychus urticae (Acari: Tetranychidae). Pestic biochem physiol 132(1):102-107

Zanardi OZ, Ribeiro L d P, Ansante TF, Santos MS, Bordini GP, Yamamoto PT, Djair Vendramim J (2015) Bioactivity of a matrine-based biopesticide against four pest species of agricultural importance. Crop Prot 67(1):160-167

\section{Submit your manuscript to a SpringerOpen ${ }^{\circ}$ journal and benefit from:}

- Convenient online submission

- Rigorous peer review

- Open access: articles freely available online

- High visibility within the field

- Retaining the copyright to your article

Submit your next manuscript at $\boldsymbol{\nabla}$ springeropen.com 